\title{
ARTICLE \\ Nuclear DNA content in Gelidium chilense (Gelidiales, Rhodophyta) from the Chilean coast
}

\author{
Contenido de ADN nuclear en Gelidium chilense (Gelidiales, \\ Rhodophyta) de la costa chilena \\ Noemi Salvador-Soler ${ }^{1 *}$, Erasmo C. Macaya ${ }^{2,4,5}$, Jordi Rull-Lluch ${ }^{3}$ \\ and Amelia Gómez-Garreta ${ }^{3}$
}

\author{
${ }^{1}$ Instituto de Ciencias Biomédicas, Facultad de Ciencias de la Salud, Universidad Autónoma de Chile, Av. Alemania, 01090. Temuco, \\ 4810101, Chile.*noemi.salvador@uautonoma.cl \\ ${ }^{2}$ Laboratorio de Estudios Algales (ALGALAB), Departamento de Oceanografía, Facultad de Ciencias Naturales y Oceanográficas, \\ Universidad de Concepción, Concepción, Casilla 160-C, Concepción, Chile \\ ${ }^{3}$ Laboratori de Botànica, Facultat de Farmàcia, Universitat de Barcelona, 08028, Barcelona, Spain \\ ${ }^{4}$ Millennium Nucleus Ecology and Sustainable Management of Oceanic Island (ESMOI), Coquimbo, Chile \\ ${ }^{5}$ Centro FONDAP de Investigaciones en Dinámica de Ecosistemas Marinos de Altas Latitudes (IDEAL)
}

\begin{abstract}
Resumen.- Durante los últimos años se ha producido un notable progreso en el número de registros sobre el tamaño del genoma para el grupo de las plantas. Sin embargo, todavía se requiere más información. Concretamente, en el caso de las algas rojas (Rhodophyta), de las $\sim 7.000$ especies descritas hasta la fecha, sólo existen datos para 196 ( $3 \%$ ). Esta investigación representa la primera estimación del tamaño del genoma del alga roja endémica del Pacífico Sudeste Gelidium chilense, proporcionando además características nucleares de la especie tales como tamaño y número por célula. Los contenidos de ADN nuclear fueron estimados a partir de las observaciones realizadas en 153 núcleos teñidos con DAPI. Las células de G. chilense mostraron una variación del contenido de ADN nuclear intraplanta de 0,2-4,0 pg. En total, 6 niveles de ploidía fueron observados en esta especie. El nivel $1 C$ fue observado solo en las células corticales mientras que el mayor nivel de ploidía (16C) fue observado en los tetrasporangios. Los valores obtenidos en los tetrasporangios indicaron que el tamaño del genoma aumenta durante la tetrasporogenesis mediante endopoliploidía (desde 4C a 16C). Por otra parte, el menor nivel de ploidía observado en las tetrasporas correspondió al 3C, lo que confirma la hipótesis de que la meiosis no ocurre en los esporangios de G. chilense. Este trabajo de investigación contribuye al conocimiento de las estrategias reproductivas relacionadas con el ciclo biológico en las especies del orden Gelidiales.
\end{abstract}

Palabras clave: Contenido de ADN nuclear, endoreduplicación, Gelidium, ciclo biológico, poliploidía

Abstract.- There has been progress in novel additions of algal data to the Plant DNA C-values database during recent years; however more information is still required. Specifically, in the case of red algae (Rhodophyta), from 7000 species described up to date, DNA C-values for only 196 species have been incorporated ( $3 \%)$. This research represents the first estimation of genome size for the Southeast Pacific endemic red alga Gelidium chilense and provides nuclear features such as number per cell and size. Nuclear DNA content estimates were obtained from measurements of 153 DAPI-stained nuclei. The cells of G. chilense showed intra-plant variation with DNA content values ranging from $0.2-4.0 \mathrm{pg}$ and a total of 6 ploidy levels were found. The lowest level (1C) was observed only in outer cortical cells whereas tetrasporangia displayed the highest levels (16C). The nuclear DNA contents obtained in tetrasporangia indicated that the genome size increases during tetrasporogenesis by endopolyploidy (from $4 \mathrm{C}$ to $16 \mathrm{C}$ ). In addition, the minimum value observed in tetraspores corresponds to a $3 \mathrm{C}$. Our results confirm the hypothesis that meiosis does not occur within the sporangia in $\mathrm{G}$. chilense. This study contributes to knowledge of reproductive strategies related with the life history of Gelidiales.

Key words: DNA content, endoreduplication, Gelidium, life history, polyploidy

\section{INTRODUCTION}

Seaweeds are key components of coastal ecosystems and are economically important as food and as a source of gelling agents because of their polysaccharide content. However, genomic information such as genome size and whole genome sequences for these organisms is scarce (Kapraun 2005, Kapraun \& Freshwater 2012). Therefore, many of the molecular mechanisms related to their life history or others traits remain unresolved (Nakamura et al. 2013). Algal genes and genome knowledge is crucial for the understanding of the evolution of the photosynthetic life in general. Furthermore, genomic data are important to ensure a sustainable aquaculture of macroalgae (Browdy et al. 2012). 
The amount of nuclear DNA in a cell is usually referred as the genome size or C-value. This represents multiples of the minimum amounts of DNA corresponding to the non-replicated haploid chromosome complement (Greilhuber et al. 2005). Interest in this genomic feature began during the late 1940s when researchers started to measure and compare DNA amounts within and between plants and animals (Swift 1950, García et al. 2013). Although the first C-values estimates were obtained using tedious and complicated chemical extraction methods, new techniques (Feulgen microdensitometry, flow cytometry and DNA image cytometry) have made estimating DNA amounts easier and faster ${ }^{1}$. Interest in such data, as well as, the number of newly estimated $\mathrm{C}$-values published has increased in recent years (Bennett \& Leitch 2011).

Information about $\mathrm{C}$-values is used in a wide range of biological fields (e.g., see Bennett et al. 2000 or Bennett \& Leitch 2011), and genomic information for algae has provided a wealth of information about the unicellular origin of higher plants and evolution of photosynthetic eukaryotes (Bowler \& Allen 2007, Tirichine \& Bowler 2011). Indeed, the data are being used for the duration of cell cycle (Francis et al. 2008), seed size and mass (Beaulieu et al. 2007), plant growth form and distribution (Ohri 2005), leaf cell size and stomatal density (Beaulieu et al. 2008, Hodgson et al. 2010), patterns of invasiveness (Kubešová et al. 2010, Lavergne et al. 2010), patterns of genome size evolution (Beaulieu et al. 2010, Leitch et al. 2010, Leitch \& Leitch 2013), and large scale comparative analyses (Levin et al. 2005). Moreover, knowledge of nuclear DNA content has practical implications, such as estimating the cost and time for whole genome sequencing projects (Kelly et al.2012) and selecting protocols for DNA fingerprinting studies (Garner 2002).

Concerning Plant DNA C-values ${ }^{2}$ land plants are one of the best-studied groups, and estimates for over 8,500 plant species have been described to date. However, the database only includes data for 253 algal species from Chlorophyta, Phaeophyceae and Rhodophyta, representing less than $2 \%$ of the described species. In addition, $\mathrm{C}$-values for South American plants are scarce and to date the Chilean Plants Cytogenetic Database ${ }^{3}$ includes none algal data. The only study including a Chilean macroalgae to our knowledge was that of Badilla et al. (2008), in which they described chromosome numbers and mean values of nuclear DNA fluorescence from different morphotypes of Pyropia columbina (Montagne) W.A. Nelson.

\footnotetext{
${ }^{1} \triangleleft$ http://data.kew.org/cvalues/>

${ }^{2}<$ ttp://data.kew.org/cvalues/>

${ }^{3}<$ ttp://www.chileanpcd.com>
}

Gelidium J.V. Lamouroux, comprised of ca. 125 species, is the largest genus within the Gelidiales (Guiry \& Guiry 2014). Some species are valuable economic resources with diverse uses as: food, agar, biofuel and paper pulp (Jeon et al. 2005, Seo et al. 2010). Gelidium chilense (Montagne) Santelices \& Montalva is a turf forming alga, endemic to Chile and southern Peru (Hoffmann \& Santelices 1997). It is the most common Gelidium species in the middle intertidal and shallow subtidal habitats of Central Chile (Santelices et al. 1981) and is an economically and ecologically important macroalgae harvested for agar extraction (Santelices 1986). DNA contents have been estimated for only six species of Gelidium (Freshwater 1993) and none from the Southeast Pacific. The aim of this paper is to provide the first estimation of genome size for G. chilense and determine if meiosis is present in the life history.

\section{MATERIALS AND METHODS}

\section{Algal material}

Tetrasporic specimens of Gelidium chilense were collected from Cocholgüe, Biobío Region, Chile (36³5'38.41' S, $72^{\circ} 58^{\prime} 43.85$ ”'W) in June 2014. Samples were collected during low tide at rocky platforms and intertidal pools. Algal material was preserved in Carnoy's fixative (3:1 of 95\% ethanol-glacial acetic acid) and stored in $70 \%$ ethanol at $4^{\circ} \mathrm{C}$ (Kapraun 2005). Voucher specimens were deposited at the BCN-Phyc. Herbarium (Documentation Center of Plant Biodiversity, University of Barcelona, Spain).

\section{Microfluorometric ANALYSIS}

Samples were rehydrated in water and softened in $5 \% \mathrm{w} / \mathrm{v}$ EDTA for $96 \mathrm{~h}$. Algal material was squashed and transferred to coverslips treated with subbing solution and then air dried and stained with $0.5 \mu \mathrm{g} \mathrm{mL}^{-1}$ 4'-6-diamidino-2-phenylindole(DAPI; Sigma Chemical Co., St. Louis, Missouri, USA). Nuclear DNA content estimates based on image analysis of DAPI-stained specimens followed a procedure modified from Kapraun \& Dunwoody (2002) and Choi et al. (1994) using a Cooled CCD Miramax RTE 782-Y high performance digital camera placed on a Leica DMRB fluorescence microscope and subsequently analyzed using MetaMorph software (Molecular Devices, Toronto, Canada). The nuclear DNA content parameters of Total Area (relative fluorescence area, in $\mu^{2}$ ) and Total Intensity (in relative fluorescence units, rfu) were estimated from microspectrophotometry and image analysis. According to Varela-Álvarez et al. (2012), microspectrophotometry followed by image analyses allows the user to observe and differentiate every single data unit obtained. Nuclei from diverse regions of 
the thallus (cortex, medulla) can be identified and checked by optical microscopy before the fluorescence microscope, thus this technique is more rigorous despite having the drawback of being slower than flow cytometry.

DAPI binds by a non-intercalative mechanism to adenine and thymine rich regions of DNA that contain at least four A-T base pairs (Portugal \& Waring 1988). Chicken erythrocytes (RBC) with a DNA content of 2.4 picograms (pg) were used as a standard to quantify nuclear DNA contents (Clowes et al. 1983). RBC can be used directly as a standard for determining amounts of DNA only when the A-T contents of both standard and experimental DNA are equivalent (Coleman et al. 1981). Chicken has a nuclear DNA base composition of 42-43 mol \% G + C (Marmur \& Doty 1962). Kapraun et al. (1993) determined the $\% \mathrm{G}+\mathrm{C}$ for three Gelidiales species and obtained values that ranged between 35-42\%. This published data indicate similar mean mol \% values for algae and linearity is presumed between DAPI-DNA binding in both RBC and algal samples (Le Gall et al. 1993).

Nuclear DNA contents were estimated by comparing the total intensity of fluorescence (rfu) values of the RBC standard and algal samples (Kapraun \& Nguyen 1994). However, it was not possible to measure the total intensity of the tetraspores nuclear content due to its interference with the auto-fluorescence associated to their cell walls and intracellular granules (Goff \& Coleman 1986). Therefore, to observe their nuclei it was necessary to overexpose the cells to the microscope light and to consider in this case the nuclear area. Consequently, the tetraspores nuclear DNA content was estimated by comparing their total area with the RBC standard, as proven useful in previous studies (Salvador et al. 2009, Bothwell et al. 2010, Varela-Alvarez et al. 2012).

Measurements of reproductive cells are considered the best way to determine the numerical relationship between rfu and C-values (Goff \& Coleman 1990). Mitotic figures in dividing somatic cells were measured to determine the $1 \mathrm{C}$ level in this study because of auto-fluorescence interference in G. chilense tetrasporangia.

Nuclear DNA content data obtained herein will be incorporated into the database of plant genome sizes (Kapraun 2005, Gregory et al. 2007) compiled and hosted by the Royal Botanic Gardens (RBG) Kew web page.

\section{Data analyses}

Data were grouped into different categories of ploidy levels according to the frequency distribution of nuclear DNA contents obtained in the histograms for each specimen or thallus portion.
The highest peak in each histogram is established as the G1 (unreplicated nuclei) in the corresponding ploidy level, with the following minor peak with twice the DNA amount as G2 (replicated nuclei). Therefore, data are sorted into groups corresponding to the ploidy levels ${ }^{4}$. Means and standard deviations were calculated for each group.

\section{Results}

A total of 580 nuclei (algae and standard together) were localized and measured. 118 nuclei were measured from vegetative thalli portions and 35 from fertile tetrasporic specimens of G. chilense. Nuclear DNA content reflects the position of a cell within a cell cycle, and the $\mathrm{C}$-values inferred from the nuclear relative fluorescent units (rfu) measurements represented $G_{1}, S$ and $\mathrm{G}_{2}$ phases of the cell population examined. The $\mathrm{G}_{1}$ and $\mathrm{G}_{2}$ peaks were represented by a Gaussian function and their $\mathrm{C}$ values were associated to the different ploidy levels specified in Table 1.

DNA content values ranged from 0.2-4.0 pg in cells of $G$. chilense (Table 1, Figs. 1 and 2). Four ploidy levels were determined in vegetative cells (Table 1, Fig. 1). The first peak in the histogram corresponds to the $1 \mathrm{C}$ ploidy level, and included

Table 1. Nuclear DNA content with corresponding Clevels in different cell types of Gelidium chilense / Contenido de ADN nuclear y valores $\mathrm{C}$ en diferentes tipos de células de Gelidium chilense

\begin{tabular}{|c|c|c|c|c|c|}
\hline & \multicolumn{2}{|c|}{$\begin{array}{l}\text { DNA content } \\
\text { (pg) }\end{array}$} & \multirow{2}{*}{$\begin{array}{l}\text { Ploidy } \\
\text { level }\end{array}$} & \multirow{2}{*}{$\begin{array}{l}\text { Cell } \\
\text { types }\end{array}$} & \multirow{2}{*}{$\mathrm{n}$} \\
\hline & mean & sd & & & \\
\hline \multirow[t]{5}{*}{ Vegetative cells } & & & & & \\
\hline & 0.23 & 0.04 & $1 \mathrm{C}$ & $\mathrm{O}$ & 23 \\
\hline & 0.4 & 0.09 & $2 \mathrm{C}$ & $\begin{array}{l}\mathrm{O} \\
\mathrm{I}\end{array}$ & 56 \\
\hline & 0.71 & 0.11 & $4 \mathrm{C}$ & $\begin{array}{c}\mathrm{I} \\
\mathrm{M}\end{array}$ & 38 \\
\hline & 1.4 & - & $8 \mathrm{C}$ & M & 1 \\
\hline \multicolumn{6}{|l|}{ Reproductive cells } \\
\hline & $0.6^{(\mathrm{a})}$ & - & $3 \mathrm{C}$ & Ts & 3 \\
\hline & 1.1 & 0.3 & $4 \mathrm{C}$ & $\mathrm{Ta}$ & 22 \\
\hline & 2.3 & 0.3 & $8 \mathrm{C}$ & $\mathrm{Ta}$ & 9 \\
\hline & 4 & - & $16 \mathrm{C}$ & $\mathrm{Ta}$ & 1 \\
\hline
\end{tabular}

O, outer cortical cells; I, inner cortical cells; M, medullary cells; Ts, tetraspores; Ta, tetrasporangia; pg, picograms; $n$, number of nuclei analyzed; ${ }^{\text {(a), }}$, value obtained by nuclear area

\footnotetext{
${ }^{4}$ ¿http:// olomouc.ueb.cas.cz/ book/analysis-endopolyploidy>
} 


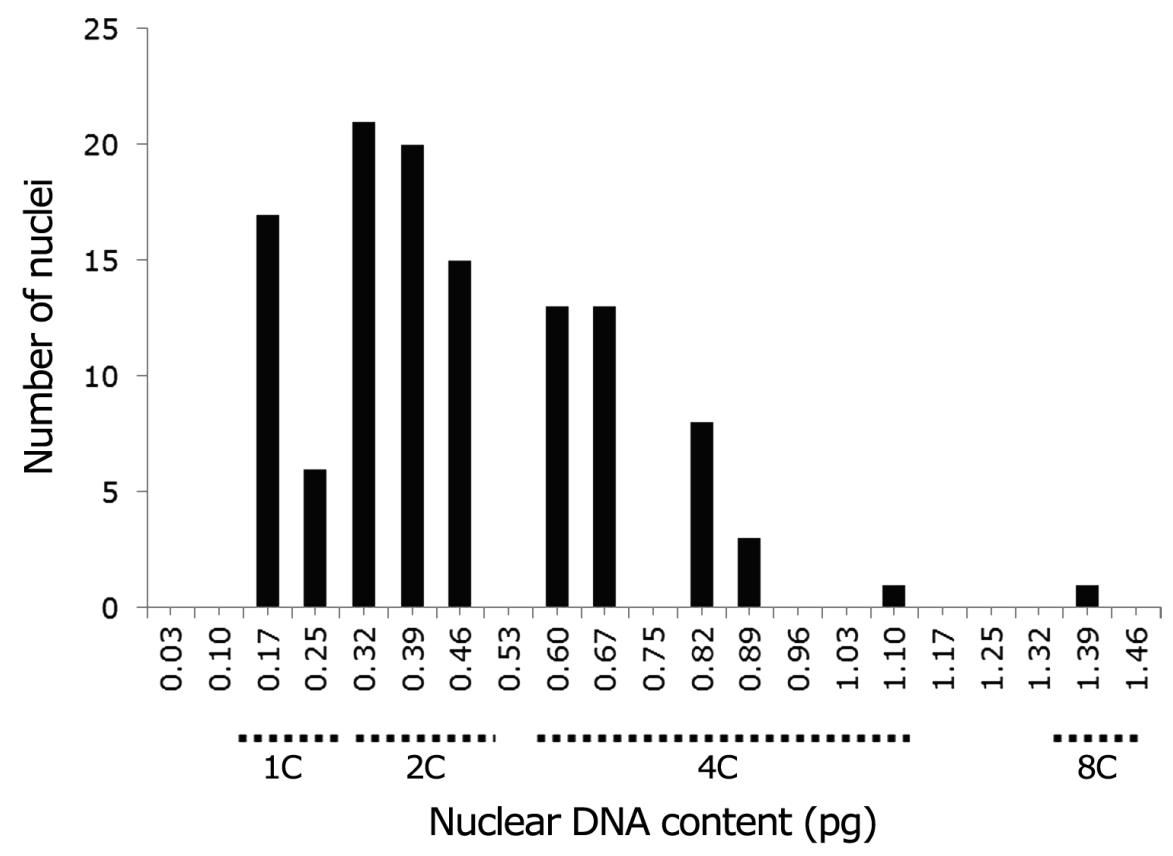

Figure 1. Frequency distribution of nuclear DNA contents and ploidy levels measured from DAPI-stained DNA for vegetative cells of Gelidium chilense / Distribución de frecuencias del contenido de ADN nuclear y niveles de ploidía obtenidos en células vegetativas de Gelidium chilense teñidas con DAPI

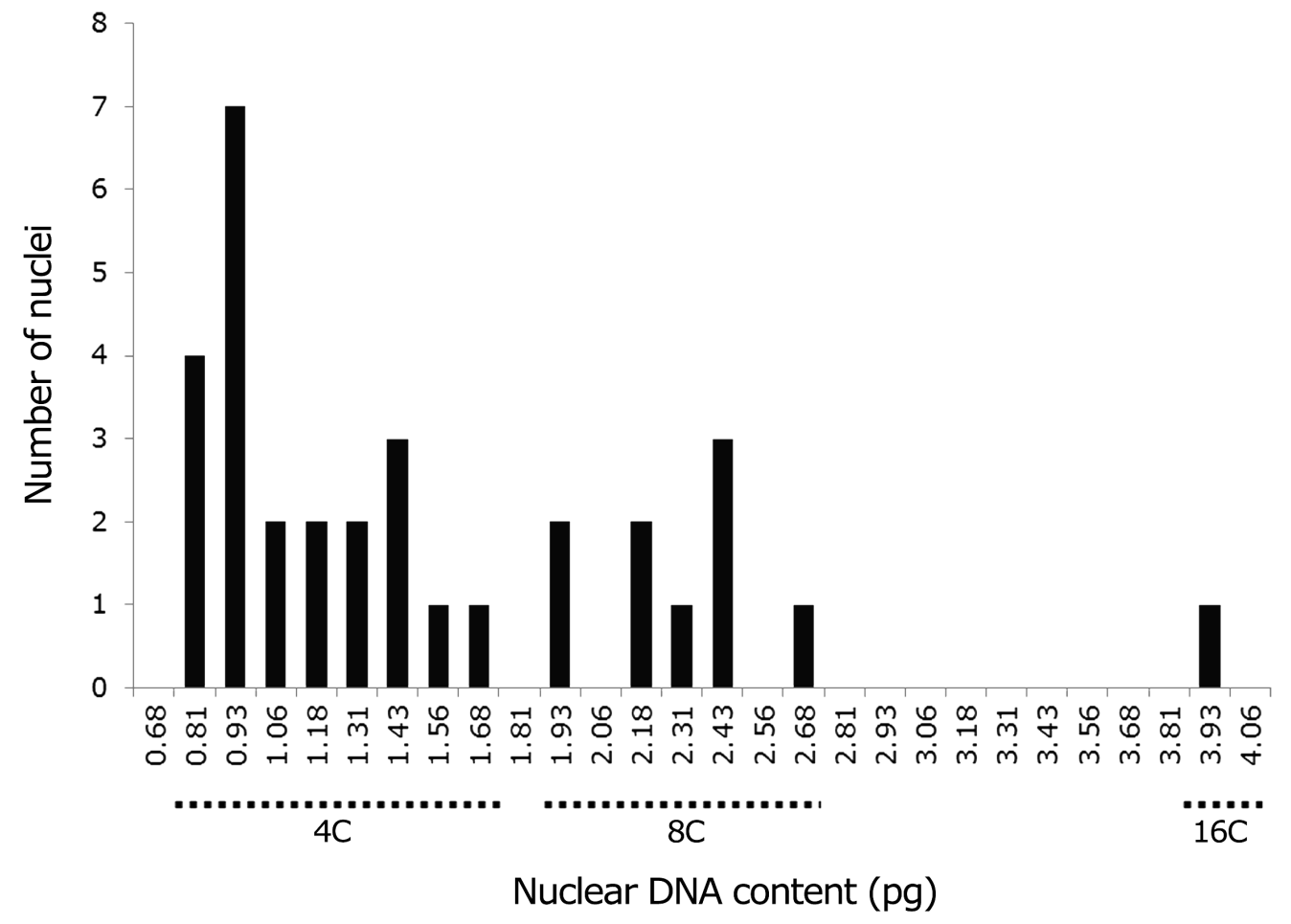

Figure 2. Frequency distribution of nuclear DNA contents and ploidy levels measured from DAPI-stained DNA for tetrasporangia cells of Gelidium chilense / Distribución de frecuencias del contenido de ADN nuclear y niveles de ploidía obtenidos en tetrasporangios de Gelidium chilense teñidos con DAPI

116 Salvador-Soler et al.

Nuclear DNA content in Gelidium chilense 
the nuclei of the outer cortical cells in G1 phase. The second peak corresponds to the $2 \mathrm{C}$ level, which included outer cortical nuclei in $\mathrm{G} 2$ phase and also inner cortical cell nuclei in $\mathrm{G} 1$ phase. The third peak corresponds to the $4 \mathrm{C}$ level integrated by inner cortical cell nuclei in G2 phase and the G1 medullary cell nuclei. A minor peak was evident at an intensity corresponding to the G2-phase nuclei of the medullary cells. The cortex was composed by uninucleate outer and inner cortical cells and trinucleate cells were present in the medulla (Fig. 3).

The mean of the nuclear DNA contents corresponding to the $1 \mathrm{C}-8 \mathrm{C}$ ploidy levels were established from the measurements of the vegetative cells, whereas the values of $3 \mathrm{C}$ and $16 \mathrm{C}$ levels were established from the measurements of reproductive cells
(Table 1, Fig. 2). The 4C and 8C ploidy levels were observed in both vegetative and reproductive cells. Ploidy levels overlapped between different cell types such as inner cortical and medullary cells (Table 1). The 1C ploidy level was determined in mitotic figures of dividing outer cortical cells (Fig. 4).

Both tetrasporangia and tetraspores were measured in reproductive cells (Figs. 5 and 6). These cells increased their size as well as their nuclear DNA content during tetrasporogenesis. Thus, a wide range of values were obtained in tetrasporangia (Table 1). The lowest ploidy level estimated for tetraspores of G. chilense was 3C.
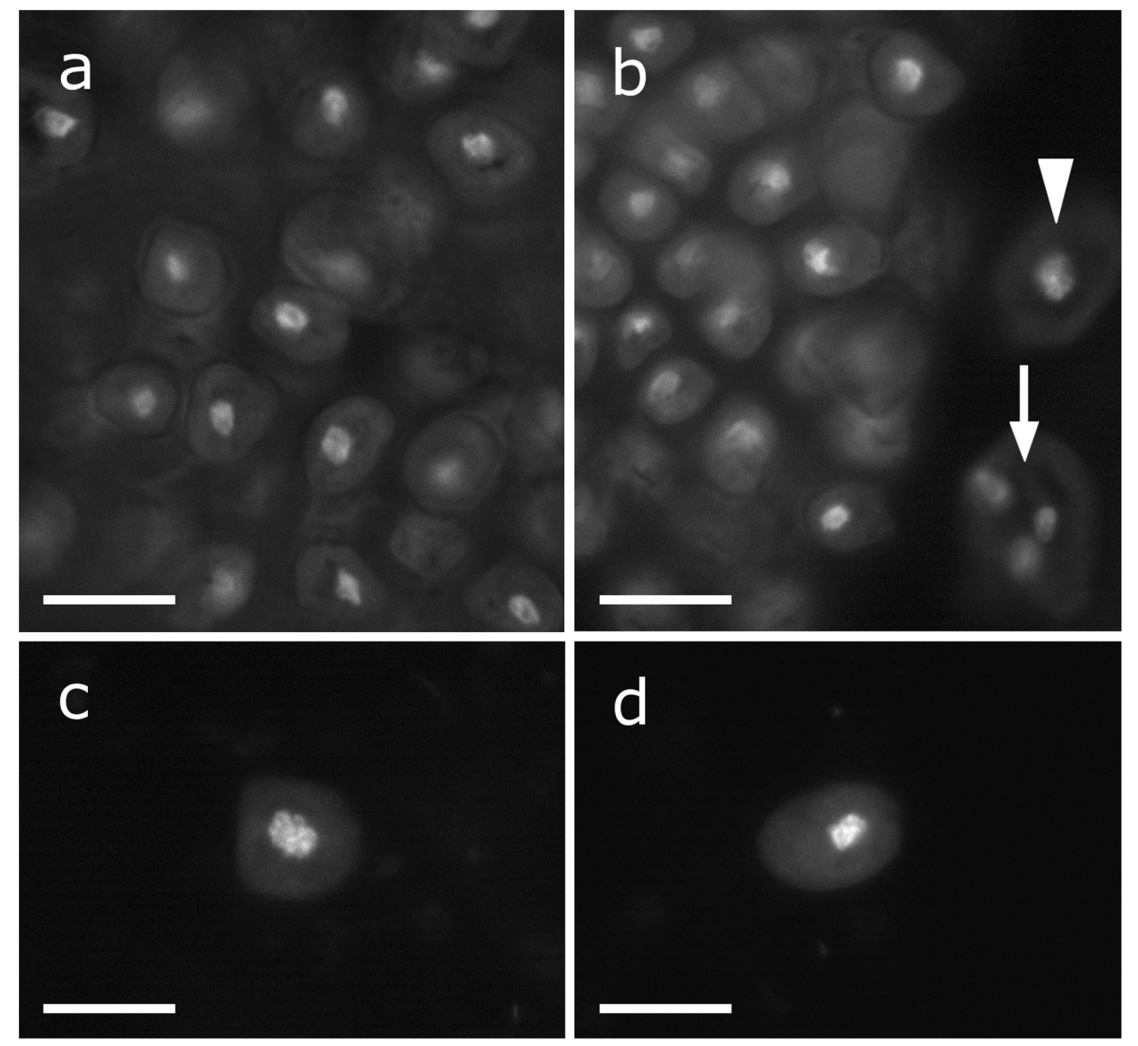

Figure 3. Cells of Gelidium chilense fixed in Carnoy's and stained with DAPI. a) Uninucleate outer cortical cells. b) Uninucleate inner cortical (arrowhead) and trinucleate medullary (arrow) cells. c) Inner cortical cells in G2 phase (4C). d) Inner cortical cells in G2 phase (4C). Scale bars represent: a-d, $5 \mu \mathrm{m} /$ Células de Gelidium chilense fijadas en Carnoy y teñidas con DAPI. a) Células corticales externas uninucleadas. b) Células corticales internas uninucleadas (punta de flecha) y células medulares trinucleadas (flecha). c) Célula cortical interna en fase G2 (4C). d) Célula cortical interna en fase G2 (4C). Escala: a-d, $5 \mu$ m 

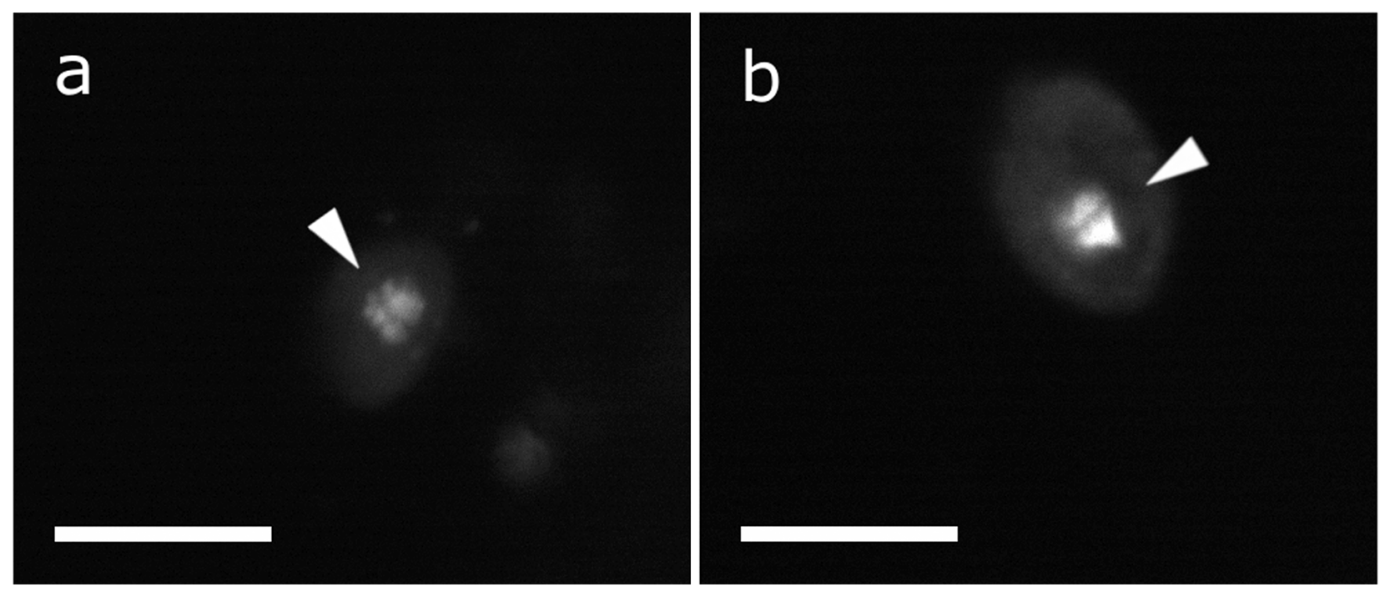

Figure 4. a-b. Mitotic figures of dividing cortical cells of Gelidium chilense stained with DAPI. Scale bars represent: a-b, $5 \mu \mathrm{m} / \mathrm{a}$-b. Figuras mitóticas de células corticales en división celular observadas en Gelidium chilense y teñidas con DAPI. Escala: a-b, $5 \mu \mathrm{m}$

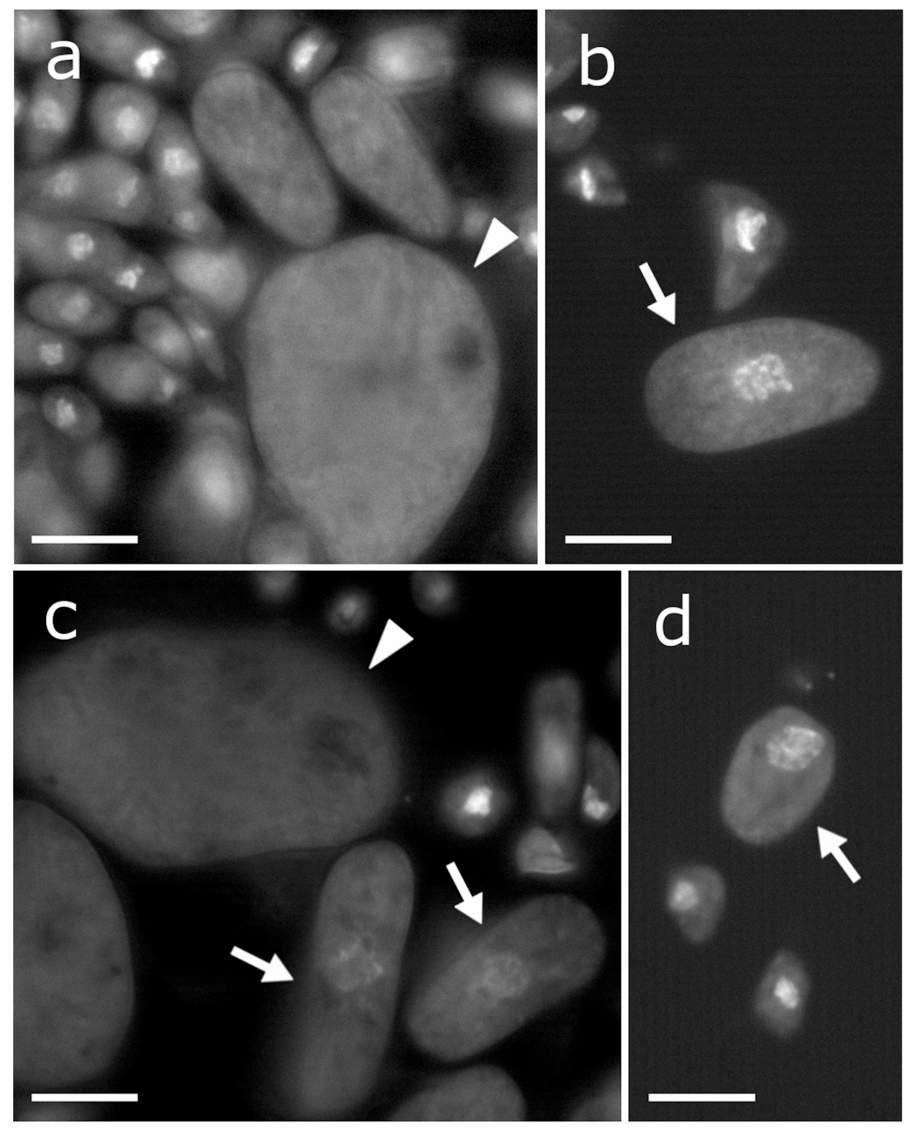

Figure 5. a-d. Inmature (arrows) and mature tetrasporangia (arrowhead) and cortical cells of Gelidium chilense fixed in Carnoy's and stained with DAPI. Scale bars represent: a-d, 5 $\mu \mathrm{m} /$ a-d. Tetrasporangios inmaduros (flechas) y maduros (punta de flecha), y células corticales de Gelidium chilense fijadas en Carnoy y teñidas con DAPI. Escala: a-d, $5 \mu \mathrm{m}$

118 Salvador-Soler et al.

Nuclear DNA content in Gelidium chilense 

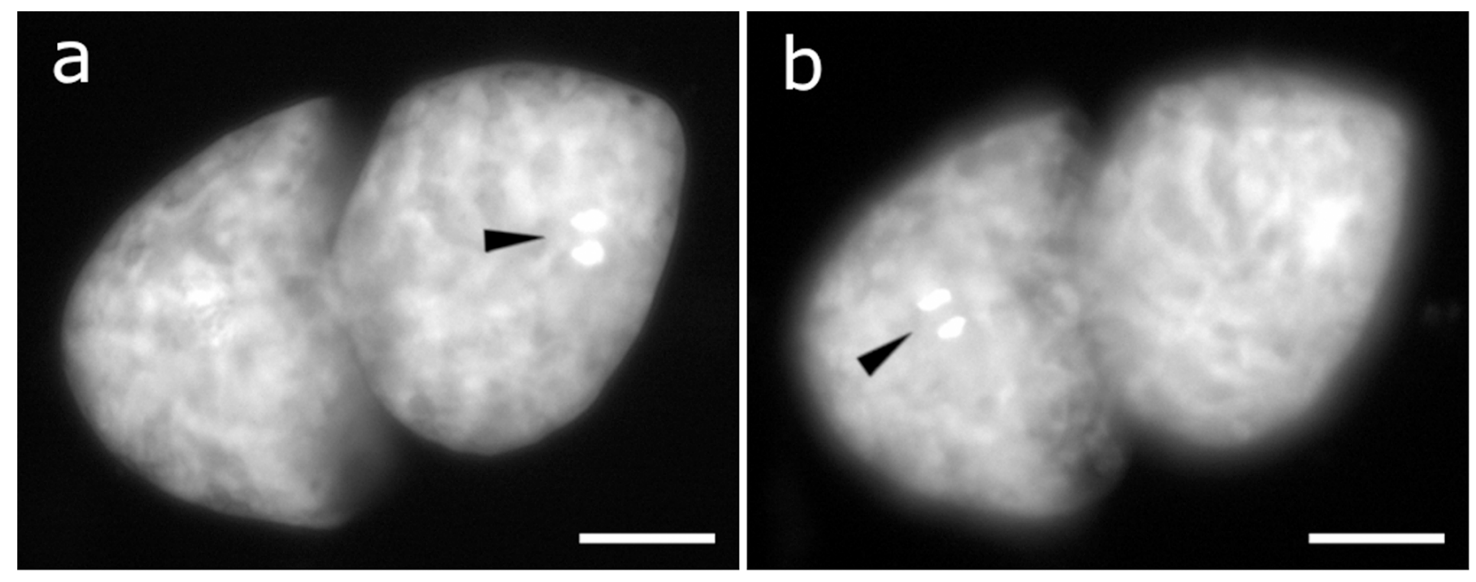

Figure 6. a-b. Overexposed nuclei (arrowhead) of tetraspores. Scale bars represent: a-b, $\mathbf{5} \boldsymbol{\mu m}$ / a-b. Núcleos de tetrasporas (punta de flecha) sobreexpuestos a la luz. Escala: a-b, $5 \mu \mathrm{m}$

\section{Discussion}

\section{NUCLEAR PATTERN}

Previous studies have revealed that red algae are considerably diverse in their nuclear cytology (Goff \& Coleman 1986, 1990; Kapraun \& Dunwoody 2002, Gómez-Garreta et al. 2010, Kapraun \& Freshwater 2012, Varela-Alvarez et al. 2012). According to Goff \& Coleman (1990), the different nuclear patterns in Florideophyceae play an important role in cell differentiation, branching and final thallus morphology.

A wide intraplant variation in DNA contents was observed in vegetative (1C-8C) and reproductive cells (3C-16C) of $G$. chilense. In vegetative cells, the variation of DNA amounts also includes polyploidy from uninucleate outer cortical (1C-2C) to the uninucleate inner cortical $(2 \mathrm{C}-4 \mathrm{C})$ to medullary cells $(4 \mathrm{C}$ 8C). In addition, the medullary cells display both polyploidy and polygenomy since they are multinucleate (Fig. 3). Our observations indicated that $G$. chilense displayed, from medulla to cortex, a process of 'incremental size decrease associated with a cascading down of DNA contents' that has been described previously in both red (Goff \& Colemann 1986) and green algae (Kapraun 1994).

According to Goff \& Coleman (1990), although homologous somatic cells in isomorphic gametophytes and sporophytes should theoretically differ two-fold in their DNA content and cell volume, in some Florideophyceae the DNA content measurements in non-apical vegetative cells show only small differences between these stages. The authors explain that this is possible because "the total DNA content of the cell is not a function of its generation, but of cell and nuclear size' (Goff \& Coleman 1990, p. 69). This is confirmed by the unexpected 1C ploidy level observed in the small cortical cells of the sporophytic samples examined.

Gelidium chilense possess cruciate tetrasporangia of 10 $\mu \mathrm{m}$ diameter and $30 \mu \mathrm{m}$ length (Hoffmann \& Santelices 1997), a large size compared to the cortical cells that produce them. Our microspectrofluorometric measurements indicated that during tetrasporogenesis the tetrasporangia increased their size as well as their nuclear DNA content (from 4C to 16C). A strong and positive correlation between nuclear DNA content and cell dimensions has been described previously in red algae (Goff \& Coleman 1990, Kapraun \& Dunwoody 2002), green algae (Kapraun \& Nguyen 1994) as well as in higher plants (Shuter et al. 1983). In addition, our observations indicate that tetrasporangia development is followed by nuclear endopolyploidy. This is in agreement with the theory that cell differentiation in plant species may be accompanied by endopolyploidization via either endomitosis or endoreduplication (Levin 2002, Bothwell et al. 2010).

Examples of endopolyploidy in reproductive cells have been observed before in both Rhodophyta and Phaeophyceae. An endoreduplication process can occur after or before sporangial production in the kelp Alaria esculenta (L.) Greville (Garbary \& Clarke 2002), and partheno-sporophytes derived from haploid filaments of the brown alga Ectocarpus are able to produce meiospores via endoreduplication (Bothwell 2010). A 
similar phenomenon was observed in the red alga Bonnemaisonia during carposporangia production and values up to $6 \mathrm{C}$ in B. clavata $\mathrm{G}$. Hamel and $8 \mathrm{C}$ in B. asparagoides (Woodward) C. Agardh were recorded for those cells (Salvador et al. 2009).

\section{DNA CONTENT}

The 2C DNA content values observed in $G$. chilense cells ( 0.4 pg) were similar to those of G. serrulatum J. Agardh (Freshwater 1993). This result was also in agreement with the narrow range of DNA content values $(2 \mathrm{C}=0.42-0.68 \mathrm{pg})$ compiled by Kapraun (2005) for several Gelidiales species.

The DNA content values obtained in the tetraspores ( 0.6 $\mathrm{pg}$ ) were twice the values listed by Kapraun (2005) in some Gelidiales (0.2-0.3 pg) and also higher than the $1 \mathrm{C}$ values obtained from the cortical cells of G. chilense. These DNA contents suggest that the values obtained in tetraspores might correspond to a $3 \mathrm{C}$ ploidy level. These results are congruent with the hypothesis based on studies of British species that life histories in Gelidium may be highly variable and meiosis may not occur in all sporangia (Dixon 1961). This may explain the differences in the ratio of life history stages for some Gelidium species in Spain (Polifrone et al.2012) and in G. chilense and Gelidium lingulatum Kützing in central Chile, where the biomass of sexual thalli throughout the year is less than $10 \%$ of the fertile biomass (Montalva \& Santelices 1981). The same hypothesis was suggested by Ponce-Márquez et al. (2009) in their cytogenetic study of Gelidium sclerophyllum W. R. Taylor, but they were unable to count the chromosomes in sporangia.

Both the large size of $G$. chilense tetrasporangia and the absence of meiosis in its life history could be adaptive strategies, the former to increase the survival of reproductive cells and the latter to produce new diploid tetrasporic thalli. In agreement with Kapraun (2005) and Destombe et al. (1992) the implication is that large spores have several advantages such as reduced predation by zooplankton, more rapid settlement and greater energy reserves for initial growth after germination.

The main conclusions of this study are: 1) the intraplant variation of DNA contents observed in vegetative cells originates from a process of 'incremental size decrease associated with a cascading down of DNA contents' from the multinucleate medullary cells to uninucleate cortical cells, 2) that the differentiation from small cortical cells to large tetrasporangia in G. chilense occurs by means of polyploidy during sporogenesis, and 3) that in the specimens of $G$. chilense examined herein the sporogenesis was not accompanied with meiosis.
This study is also the first report of DNA C-values from an endemic Chilean red alga. Additional studies on the nuclear DNA content of Chilean Gelidium species will increase the DNA C-values database and help to understand the life history of this economically important group of agarophytes.

Finally, detailed cytological studies are important for clarifying important features of reproductive structures and life histories of algae as well as associating the intraplant variation of the nuclear DNA contents with their morphology.

\section{ACKNOWLEDGMENTS}

This work was supported by 'DIP 40-2015’ project of Dirección de Investigación y Postgrado, Universidad Autónoma de Chile, Temuco, Chile.

\section{LITERATURA CITADA}

Badilla R, E Von Brand \& G Collantes. 2008. Karyotypes and microfluorometric studies in Porphyra columbina Montagne (Bangiales, Rhodophyta), with reference to morphology and sexuality. Revista de Biología Marina y Oceanografía 43(1): 17-23.

Beaulieu JM, AT Moles, IJ Leitch, MD Bennett, JB Dickie \& CA Knight. 2007. Correlated evolution of genome size and seed mass. New Phytologist 173: 422-437.

Beaulieu JM, IJ Leitch, S Patel, A Pendharkar \& CA Knight. 2008. Genome size is a strong predictor of cell size and stomatal density in angiosperms. New Phytologist 179: 975-986.

Beaulieu JM, S Smith \& IJ Leitch. 2010. On the tempo of genome size evolution in angiosperms. Journal of Botany 2010, <doi:10.1155/2010/989152>

Bennett MD \& IJ Leitch. 2011. Nuclear DNA amounts in angiosperms -targets, trends and tomorrow. Annals of Botany 107: 467-590.

Bennett MD, P Bhandol \& IJ Leitch. 2000. Nuclear DNA amounts in angiosperms and their modern uses-807 new estimates. Annals of Botany 86: 859-909.

Bothwell JH, D Marie, AF Peters, JM Cock \& SM Coelho. 2010. Role of endoreduplication and apomeiosis during parthenogenetic reproduction in the model brown alga Ectocarpus. New Phytologist 188: 111-121.

Bowler C \& AE Allen. 2007. The contribution of genomics to the understanding of algal evolution. In: Brodie J \& J Lewis (eds). Unravelling the algae: the past, present, and future of algal systematics, pp. 331-340. CRC Press, Boca Raton.

Browdy CL, G Hulata, Z Liu, GL Allan, C Sommerville, T Passos de Andrade, R Pereira, C Yarish, M Shpigel, T Chopin, S Robinson, Y Avnimelech \& A Lovatelli. 2012. Novel and emerging technologies: can they contribute to improving aquaculture sustainability? In: Subasinghe RP, JR 
Arthur, DM Bartley, SS De Silva, M Halwart, N Hishamunda, CV Mohan \& P Sorgeloos (eds). Farming the waters for people and food. Proceedings of the Global Conference on Aquaculture 2010, pp. 149-191. FAO, Rome and NACA, Bangkok.

Choi HG, YK Lee \& IK Lee. 1994. Measurement of DAPI stained DNA in Dasysiphonia chejuensis Lee et West (Rhodophyta) by a video interfaced digital image processor. Korean Journal of Phycology 9: 21-28.

Clowes AW, MA Reidy \& MM Clowes. 1983. Kinetics of cellular proliferation after arterial injury. I. Smooth muscle growth in absence of endothelium. Laboratory Investigations 49:327-333.

Coleman AW, MJ Maguire \& JR Coleman. 1981. Mithramycin- and 4, 6-diamidino-2-phenylindole (DAPI)staining for fluorescence microspectrophotometric measurement of DNA in nuclei, plastids, and virus particles. Journal of Histochemistry and Cytochemistry 29: 959-968.

Destombe C, J Godin, C Lefebvre, O Dehorter \& P Vernet. 1992. Differences in dispersal abilities of haploid and diploid spores of Gracilaria verrucosa (Gracilariales, Rhodophyta). Botanica Marina 35: 93-98.

Dixon PS. 1961. On the classification of the Florideae with particular reference to the position of the Gelidiaceae. Botanica Marina 8: 1-16.

Francis D, MS Davies \& PB Barlow. 2008. A strong nucleotypic effect of DNA C-value on the cell cycle regardless of ploidy level. Annals of Botany 101: 747-757.

Freshwater WD. 1993. Cytophotometric estimation of inter and intraspecific variation in nuclear DNA content in ten taxa of the Gelidiales (Rhodophyta). Journal of Experimental Marine Biology and Ecology 166: 231-239.

Garbary DJ \& B Clarke. 2002. Intraplant variation in nuclear DNA content in Laminaria saccharina and Alaria esculenta (Phaeophyceae). Botanica Marina 45: 211-216.

García S, IJ Leitch, A Anadon-Rosell, MÁ Canela, F Gálvez, T Garnatje, A Gras, O Hidalgo, E Johnston, G Mas de Xaxars, J Pellicer, S Siljak-Yakovlev, J Vallès, D Vitales \& MD Bennett. 2013. Recent updates and developments to plant genome size data bases. Nucleic Acids Research 27: 1-8.

Garner TWJ. 2002. Genome size and microsatellites: the effect of nuclear size on amplification potential. Genome 45: 212215.

Goff LJ \& AW Coleman. 1986. A novel pattern of apical cell polyploidy, sequential polyploidy reduction and intercellular nuclear transfer in the red alga Polysiphonia. American Journal of Botany 73: 1109-1130.

Goff LJ \& AW Coleman. 1990. DNA: Microspectrofluorometric studies. In: Cole KM \& RG Sheath (eds). Biology of the red algae, pp. 43-72. Cambridge University Press, New York.
Gómez-Garreta A, MA Ribera-Siguan, N Salvador-Soler, J Rull-Lluch \& DF Kapraun. 2010. Fucales (Phaeophyceae) from Spain characterized by large scale discontinuous nuclear DNA contents consistent with ancestral cryptopolyploidy. Phycologia 49: 64-72.

Gregory TR, JA Nicol, H Tamm, B Kullman, K Kullman, IJ Leitch, BG Murray, DF Kapraun, J Greilhuber \& MD Bennett. 2007. Eukaryotic genome size databases. Nucleic Acids Research 35: D332-D338.

Greilhuber J, J Doležel, MA Lysak \& MD Bennett. 2005. The origin, evolution and proposed stabilization of the terms 'Genome Size' and 'C-Value' to describe nuclear DNA contents. Annals of Botany 95: 255-260.

Guiry MD \& GM Guiry. 2014. AlgaeBase. World wide electronic publication, National University of Ireland, Galway. <http://www.algaebase.org>

Hodgson JG, M Sharafi, A Jalili, S Diaz, G MontserratMartí, C Palmer, B Cerabolini, S Pierce, B Hamzehee, Y Asri, Z Jamzad, P Wilson, JA Raven, SR Band, S Basconcelo, A Bogard, G Carter, M Charles, P CastroDíez, JH Cornelissen, G Funes, G Jones, M Khoshnevis, N Pérez-Harguindeguy, MC PérezRontomé, FA Shirvany, F Vendramini, S Yazdani, R Abbas-Azimi, S Boustani, M Dehghan, J GuerreroCampo, A Hynd, E Kowsary, F Kazemi-Saeed, B Siavash, P Villar-Salvador, R Craigie, A Naqinezhad, A Romo-Díez, L de Torres Espuny \& E Simmons. 2010. Stomatal vs. genome size in angiosperms: the somatic tail wagging the genomic dog? Annals of Botany 105: 573-584.

Hoffmann A \& B Santelices. 1997. Flora marina de Chile Central, 434 pp. Ediciones Universidad Católica de Chile, Santiago.

Jeon YJ, Y Athukorala \& J Lee. 2005. Characterization of agarose product from agar using DMSO. Algae 20: 61-67.

Kapraun DF. 1994. Cytophotometric estimation of nuclear DNA contents in thirteen species of the Caulerpales (Chlorophyta). Cryptogamic Botany 4: 410-418.

Kapraun DF. 2005. Nuclear DNA content estimates in multicellular eukaryotic green, red and brown algae: phylogenetic considerations. Annals of Botany 95: 7-44.

Kapraun DF \& JT Dunwoody. 2002. Relationship of nuclear genome size to some reproductive cell parameters in the Florideophycidae (Rhodophyta). Phycologia 41: 507-516.

Kapraun DF \& DW Freshwater. 2012. Estimates of nuclear DNA content in red algal lineages. AoB Plants 2012, <doi: 10.1093/aobpla/pls005>

Kapraun DF \& MN Nguyen. 1994. Karyology, nuclear DNA quantification and nucleus cytoplasmic domain variations in some multinucleate green algae. Phycologia 33: 42-52.

Kapraun DF, JA Dutcher \& DW Freshwater. 1993. DNA base composition heterogeneity in some Rhodophyta. Cryptogamic Botany 4: 97-106. 
Kelly LJ, AR Leitch, MF Fay, S Renny-Byfield, J Pellicer, J Macas \& IJ Leitch. 2012. Why size really matters when sequencing plant genomes. Plant Ecology \& Diversity 5: 415425.

Kubešová M, L Moravcová, J Suda, V Jarošík \& P Pyšek. 2010. Naturalized plants have smaller genomes than their non-invading relatives: a flow cytometric analysis of the Czech alien flora. Preslia 82: 81-96.

Lavergne S, NJ Muenke \& J Molofsky. 2010. Genome size reduction can trigger rapid phenotypic evolution in invasive plants. Annals of Botany 105: 109-116.

Le Gall Y, S Brown, D Marie, M Mejjad \& B Kloareg. 1993. Quantification of nuclear DNA and G-C content in marine macroalgae by flow cytometry of isolated nuclei. Protoplasma 173: 123-132.

Leitch IJ \& AR Leitch. 2013. Genome size diversity and evolution in land plants. In: Leitch IJ, J Greilhuber, J Dolezel \& JF Wendel (eds). Plant genome diversity, vol 2, Physical structure, behaviour and evolution of plant genomes, pp. 307322. SpringerVerlag, Wien.

Leitch IJ, JM Beaulieu, MW Chase, AR Leitch \& MF Fay. 2010. Genome size dynamics and evolution in monocots. Journal of Botany 2010, <doi: 10.1155/2010/989152>

Levin DA. 2002. The role of chromosomal change in plant evolution, $230 \mathrm{pp}$. Oxford University Press, Oxford.

Levin DA, BG Palestis, RN Jones \& R Trivers. 2005. Phyletic hot spots for B chromosomes in angiosperms. Evolution 59: 962-969.

Marmur J \& P Doty. 1962. Determination of the base composition of desoxyribonucleic acid from its thermal denaturation temperature. Journal of Molecular Biology 5: 109-118.

Montalva S \& B Santelices. 1981. Interspecific interference among species of Gelidium from central Chile. Journal of Experimental Marine Biology and Ecology 53(1): 77-88.

Nakamura Y, N Sasaki, M Kobayashi, N Ojima, M Yasuike, Y Shigenobu, M Satomi, Y Fukuma, K Shiwaku, A Tsujimoto, T Kobayashi, I Nakayama, F Ito, K Nakajima, M Sano, T Wada, S Kuhara, K Inouye, T Gojobori \& K Ikeo. 2013. The first symbiontfree genome sequence of marine red alga, susabinori (Pyropia yezoensis). PLOS ONE 8(3): e57122.

Ohri D. 2005. Climate and growth form: the consequences for genome size in plants. Plant Biology 7: 449-458.
Polifrone M, MC Gil-Rodríguez, S Domínguez Alvárez, M Stroobant \& MA Viera-Rodríguez. 2012. Reproductive phenology of three species of Gelidiales (Rhodophyta) in two macroalgal communities from Tenerife (Atlantic Ocean, Canary Islands, Spain). Anales del Jardín Botánico de Madrid 69: 247-252.

Ponce-Márquez ME, D Rodríguez, N López, L Alba-Lois \& MA Aguilar. 2009. Estudio citogenético de poblaciones mexicanas de Gelidium sclerophyllum (Gelidiales, Rhodophyta). Hidrobiológica 19(2): 85-93.

Portugal J \& M Waring. 1988. Assignment of DNA binding sites for DAPI and bisbenzimide (Hoeschst 33258). Comparative foot printing study. Biochimica et Biophysica Acta 949: 158-168.

Salvador N, A Gómez-Garreta \& MA Ribera-Siguan. 2009. Somatic meiosis in the life history of Bonnemaisonia asparagoides and Bonnemaisonia clavata (Bonnemaisoniales, Rhodophyta) from the Iberian Peninsula. European Journal of Phycology 44: 381-393.

Santelices B. 1986. The wild harvest and culture of the economically important species of Gelidium in Chile. In: Doty MS, JF Caddy \& B Santelices (eds). Case studies of seven commercial seaweed resources. FAO Fisheries Technical Paper 281: 165-192. FAO, Rome.

Santelices B, S Montalva \& P Oliger. 1981. Competitive algal community organization in exposed intertidal habitats from central Chile. Marine Ecology Progress Series 6: 267276.

Seo YB, YW Lee, CH Lee \& HC You. 2010. Red algae and their papermaking. Bioresource Technology 101: 2549-2553.

Shuter BJ, JE Thomas, WD Taylor \& AM Zimmerman. 1983. Phenotypic correlates of genomic DNA content in unicellular eukaryotes and other cells. The American Naturalist 122: 26-44.

Swift H. 1950. The constancy of deoxyribose nucleic acid in plant nuclei. Proceedings of the National Academy of Sciences of the United States of America 36: 643-654.

Tirichine L \& C Bowler. 2011. Decoding algal genomes: tracing back the history of photosynthetic life on Earth. The Plant Journal 66: 45-57.

Varela-Álvarez E, A Gómez-Garreta, J Rull-Lluch, N Salvador-Soler, EA Serrao \& MA Ribera-Siguan. 2012. Mediterranean species of Caulerpa are polyploid with smaller genomes in the invasive ones. PLOS ONE 7: e47728. 